\title{
Improving the process of coal extraction based on the parameter optimization of mining equipment
}

\author{
Volodymyr Hrinov ${ }^{1}$, and Andrii Khorolskyi ${ }^{1 *}$ \\ ${ }^{1}$ Institute of Physics of the Mining Processes of National Academy of Sciences of Ukraine, \\ 2a Simferopolska St., 49005 Dnipro
}

\begin{abstract}
The aim of this paper is to develop and validate methods of choosing the means of the mining face mechanization. This paper analyses existing methods of optimizing processes in mining. It was established that the effectiveness of the performance map of coal field is formed by a group of technological, operational, and economic parameters which can be represented as a vector of solutions. To find the optimal solution, it was suggested to use network models and graphs. The essence of the technique is to represent the input and output (production level, prime cost) resource flows in an organized structure. Regularities of forming technological schemes of coalfield operation with a given level of performance, taking into account the relationship between technological parameters of mining face, operational parameters of the stoping equipment, technical and economic performance are defined. We developed the system for decisionmaking support, which allows optimizing operational parameters, reducing the production prime cost, and selecting the structure of the mechanized complex of stoping equipment with a specified level of performance. This paper describes approaches that can be used at the design stage of mining face and in the process of operation.
\end{abstract}

\section{Introduction}

The coal industry is one of the most resource-intensive in the energy sector. For the effective operation of coalfields, it is necessary to solve a number of issues that are associated with the justification of rational operation of the stoping equipment, increase in the productivity of the mining face, decrease in the production prime cost, etc. Solving each task separately does not allow increasing the overall efficiency. Moreover, a group of technological, operational, and economic parameters forms performance indicators, so it is necessary to develop an integrated approach. Today, there is a number of methods and means of decision-making support in mining, which are aimed at improving the production process. One uses most frequently the multi-criteria decision analysis (MCDA), the essence of which is in priority setting, selecting the most important factors with further optimization. It is worth noting that, because of using MCDA, the solution is not optimal but efficient according to a specified function of "usefulness".

\footnotetext{
*Corresponding author: khorolskiyaa@ukr.net
} 
In mining, one uses the analytic hierarchy process (AHP), designed by T. Saaty and adapted by scientists to operating condition of enterprises in the mining complex: M. Ataei [1], S. Alpay [2]. However, there is a number of difficulties: importance and priority of the criterion establish the decision-maker (DM) - for the accurate decision-making, there should be consistency between DMs (Pareto optimality); a great number of samples and a poll do not always guarantee the right choice; in addition, the selection criteria do not always correspond to the task [3]. Given the specificity of the mining industry, we developed modifications of the method taking into account deviations from the model of rational choice (TODIM) [4], as well as deviations from the "ideal" value with subsequent normalization [5] (Grey-AHP).

Also, the wide-spread is the method of preferences analysis (PROMETHEE), the essence of which is to set the preference function, comparison of options, and subsequent ranking of obtained preference functions. This method is used by Wang Chen [6] to solve tasks of transporting coal in the mining face, Zhang Jianping [7] to balance the supply of materials. The use of this method is difficult because nobody knows weighting coefficients for each parameter group (equipment, technological parameters, technical and economic indicators).

Analysis of the AHP method and its varieties (TODIM, Grey-AHP), as well as the method of preferences analysis PROMETHEE has found out that there is an issue of incommensurability and inconsistency in the selection of criteria. Therefore, the idea of adopting a "compromise solution" appeared [8]. This method was used at the stage of design transportation chains [9], to solve the tasks of production organization in the mining face [10]. However, there is the issue of "indistinct" uncertain objects that have different characteristics, for example: roof stability, soil rock category of opening, etc. To solve this issue, it was proposed to use fuzzy-set methods [11], while for the efficient design there should be the basis for "good" design decisions [12], which can be represented by graphs and network models.

The analysis of papers [1, 2, 4-12] allowed us to find out that the increase in the efficiency of technological schemes for the operation of coalfields is impossible without optimization of parameters of the stoping equipment. To achieve this task, one can use methods of the decision-making theory that are based on the comparison of possible solutions and priority setting. There are also factors that do not allow efficiently applying these approaches for the solution of tasks in the optimization of parameters of the stoping equipment:

- iincommensurability of efficiency criteria values; for example, the daily performance at mines of Ukraine is 500 to $3000 \mathrm{t}$ /day, the level of significant preference $H_{d}=0.5$ is adopted based on the condition of the break-even $Q \geq 1.000 \mathrm{t} /$ day, and the maximum preference $H_{d}=1.0$ will correspond to the maximum capacity $Q \geq 3000 \mathrm{t} /$ day; in fact, $66 \%$ of performance indicators values will be preferred;

- when choosing means of the mining face mechanization in addition to quantitative criteria (performance, equipment life, prime cost, etc.) one also uses qualitative criteria relationship with the pan line of armoured face conveyor, consistency of the advance increment of powered support and shearer, interrelation between the armoured face conveyor advance system and the shearer transfer system, etc.;

- as previously stated $[11,12]$, the search for the optimal solution to the task is to analyse good (rational for specific conditions) solutions, but this is impossible without the presence of the "bank of situational solutions";

- listed methods of decision-making [1 - 12] are based on the use of adjacency matrices with the dimensionality $n \times m$, where $n$ is the number of alternatives, and $m$ is the number of criteria that match the alternative $n$; for the final decision-making, we use methods of 
linear programming, special expensive software [13, 14]; at the same time, methods of discrete mathematics allow us to successfully use relevant approaches without additional resources.

Therefore, the process of improving the technology of mechanized coal mining is in support of rational (good) operating conditions with subsequent optimization of parameters of the stoping equipment. There is an area of "rational design" [15], and for our study, this is a set of conditions for the operation of the stoping equipment (layer thickness, face length, rocks length, roof length), which correspond to technical and economic, operational parameters.

To solve this task, we can use network models and graphs. In the paper [16], there is the methodology of selecting the stoping equipment using graphs and network models, and in the paper [17], there is its practical use. It is worth noting that this approach was used to solve transportation issues [18], tasks for the resource allocation at the mine [19], as well as for ventilation of mine workings [20], as well as surface mining of mineral deposits [21, 22].

Thus, establishing regularities of forming technological schemes of the stoping equipment with the set performance level, depending on technological, operational, economic parameters, is a topical scientific task. The aim of this paper is to develop a tool for optimizing parameters of the mining equipment. To do this, it is necessary to establish the rational area for the design of hardware, substantiate the system of principles for selecting the stopping equipment, develop the mathematical model, and offer the program implementation.

\section{System principles for selecting the stoping equipment}

In relation to the aim of the study, general system principles [23-25] are as follows:

- integrity, i.e. the mining equipment is considered as a single structure "mechanical powered support - shearer - face armoured face conveyor" without separation into individual components;

- hierarchy, i.e. one considers the relationship not only between the types of stoping equipment (for example: shearer-armoured face conveyor) but also between the assembly units of equipment (for example: the armoured face conveyor pan line and the shearer transfer system);

- structuring, i.e. the possibility of optimizing not the entire structure "powered support shearer - armoured face armoured face conveyor", but only certain levels of "powered support - shearer", "shearer - armoured face conveyor";

- consistency, i.e. operating parameters of each type of equipment (layer thickness, mining face length, seam inclination) correspond to operating parameters of the structure "powered support - shearer - armoured face conveyor";

- multiplicity, i.e. the existence of standard models ("bank of good solutions" [12]) for a set of presented options.

Compliance with all principles allows obtaining the property of the "structural optimization" $[26,27]$ - the process of obtaining a series of system effects for the optimization of the objective function depending on given limitations.

As for the structure of the stoping equipment, we should consider the area of rational design, i.e. operating conditions in which indicators will be maximum and meet the breakeven condition (for mines of Donbas $Q \geq 1000 \mathrm{t} /$ day).

As noted earlier, the efficiency of the production process $P$ is affected by technological operational parameters $P_{T}$, means of mechanization $P_{E}$, and the production prime cost $P_{C}$. Then, the vector $p\left(P_{T}, P_{E}, P_{C}\right)$ will represent the rational option of integration of the stopping equipment. From the optimality condition: 


$$
p\left(P_{T}, P_{E}, P_{C}\right)=\min \left(P_{T}, P_{E}, P_{C}\right),
$$

where $\quad p=\left\{P_{1 T}, P_{2 T}, \cdots, P_{N T} ; P_{1 E}, P_{2 E}, \cdots, P_{E T} ; P_{1 C}, P_{2 C}, \cdots, P_{N C}\right\}-$ the vector and its components $P_{1 T}, P_{2 T}, \cdots, P_{N T}$ meet rational technological parameters of the working area, $P_{1 E}, P_{2 E}, \ldots, P_{N E}-$ types of the stoping equipment, $P_{1 C}, P_{2 C}, \ldots, P_{N C}-$ the production prime cost.

The group of technological parameters of the mining face $P_{1 T}, P_{2 T}, \ldots, P_{N T}$ includes the length of the working area $l_{n}$ and the layer thickness $m_{n}$. The group of the "mining equipment" corresponds to the structure "powered support $t_{n}$, shearer $c_{n}$, armoured face conveyor $k_{n}$ ", which can provide the daily performance $q_{n n}$ at the level of $Q \geq 1000 \mathrm{t} /$ day.

The level of costs for the purchase of machinery $Z_{n}$ and equipment life $R_{n}$ form the specific cost of production $P_{1 C}, P_{2 C}, \ldots, P_{N C}$.

Then, the mathematical meaning of the proposed approach can be formed as follows: the totality of types of the mining equipment $\left\langle t_{n}, c_{n}, k_{n}\right\rangle$, which is operated under given operating conditions $\left\langle t_{n}, m_{n}\right\rangle$, generates the level of performance $q_{n n}$ at the prime cost $s_{n}$. It should be noted that any groups of parameters and performance criteria could be specified, as long as they meet the objectives of the study. In accordance with planned parameters, one can set the scope of rational design (Table 1).

Table 1. The scope of rational design for solving the task of optimizing the mining equipment.

\begin{tabular}{|l|c|c|}
\hline \multicolumn{1}{|c|}{ Indicator } & Criterion value & Limitation form \\
\hline Layer thickness $m_{n}, \mathrm{~m}$ & $M \subseteq H \Leftrightarrow \forall m_{n} \in M: m_{n} \in H$ & $M \subseteq H$ \\
\hline Length of the mining face $l_{n}, \mathrm{~m}$ & $L \subseteq W \Leftrightarrow \forall l_{n} \in L: l_{n} \in W$ & $L \subseteq W$ \\
\hline Powered support $t_{n}$ & $T \subseteq R \Leftrightarrow \forall t_{n} \in T: t_{n} \in R$ & $T \subseteq R$ \\
\hline Shearer $c_{n}$ & $C \subseteq S \Leftrightarrow \forall c_{n} \in C: c_{n} \in S$ & $C \subseteq S$ \\
\hline Armoured face conveyor $k_{n}$ & $K \subseteq A \Leftrightarrow \forall k_{n} \in K: k_{n} \in A$ & $K \subseteq A$ \\
\hline $\begin{array}{l}\text { Funds for the purchase of equipment } Z_{n}, \\
\text { mln UAH }\end{array}$ & $Z_{n} \rightarrow \min$ & $Z_{\text {max }} \leq Z_{n} \leq Z_{\min }$ \\
\hline equipment life $R_{n}$, mln tonnes & $R_{n} \rightarrow \max$ & $R_{\min } \leq R_{n} \leq R_{\max }$ \\
\hline
\end{tabular}

where $M, L$ - the subset of rational operational parameters, and $H, W$ - the great number of possible technological parameters; $T, C, K$ - the subset of rational types of the mining equipment, $R, S, A$ - the great number of existing types of equipment.

From Table 1, it is seen that the given level of performance $Q$ is generated only when technological parameters $\left\langle l_{n}, m_{n}\right\rangle$ are rational: $l_{n} \in L, m_{n} \in M$, i.e. they are at the subset of rational operational parameters $M, L$. In addition, the means of mechanization $\left\langle t_{n}, c_{n}, k_{n}\right\rangle$ have a high level of interrelation: $t_{n} \in T, c_{n} \in C, k_{n} \in K$, where $T, C, K-$ the subset of rational types of equipment. The important condition is that the funds for the purchase of mechanization means should be kept at their minimum $Z_{n} \rightarrow \min$ and the equipment life - at the maximum $R_{n} \rightarrow$ max .

To optimize operational parameters, one should formalize them, i.e. present in the form of a network model. Then, the shortest route of the network model $g_{1}$ will correspond to the optimal solution. Conditions (2) and (3) shall be met: 


$$
\begin{aligned}
& \left(m_{1} \cdots m_{n}\right) \rightarrow\left(l_{1} \cdots l_{n}\right) \rightarrow\left(t_{1} \cdots t_{n}\right) \rightarrow\left(c_{1} \cdots c_{n}\right) \rightarrow \\
& \rightarrow\left(k_{1} \cdots k_{n}\right) \rightarrow\left(v_{1} \cdots v_{n}\right) \rightarrow\left(s_{11} \cdots s_{1 n}\right) \rightarrow g_{1} \\
& (i ; j)=s_{n}-\text { the route exists, }(i ; j)=\infty-\text { the route is missing, }
\end{aligned}
$$

where (2) - the condition for the existence of the alternative, i.e. the optimization requires that the route passes through vertices, which correspond to the layer thickness $\left(m_{1} \ldots m_{n}\right)$, the length of the mining face $\left(l_{1} \ldots l_{n}\right)$, powered support types $\left(t_{1} \ldots t_{n}\right)$, shearer types $\left(c_{1} \ldots c_{n}\right)$, armoured face conveyor types $\left(k_{1} \ldots k_{n}\right)$, the level of performance $\left(v_{1} \ldots v_{n}\right)$, the production prime cost $\left(s_{11} \ldots s_{1 n}\right)$; (3) - the condition for the existence of the link between vertices, i.e. the production prime cost for each type of equipment $s_{n}$ can be expressed as the distance between vertices $(i ; j)$ of the network model.

Then, the task of optimization by the parameter "prime cost" can be solved as follows:

1) define rational types of the mining equipment $T, C, K$ and present them as vertices of the network model $\left(t_{1} \ldots t_{n}\right),\left(c_{1} \ldots c_{n}\right),\left(k_{1} \ldots k_{n}\right)$;

2) define the production prime cost for each type of equipment $s_{n}=Z_{n} / R_{n}$ and present it as the length of the route $(i, j)$ between vertices; if the interrelation between types of equipment is missing, then $(i, j)=\infty$;

3) find the best solution that corresponds to the shortest route from the vertice $m_{1}$ to the vertice $g_{1}$ using optimization algorithms or methods of linear programming.

The optimization parameter for the route length can be any characteristic of the process (maintenance costs, energy expenditure level, personnel number), and vertices can be represented by types of equipment, intermediate points, stages, etc.

We shall use mines "Krasnolymanska" and "Kotliarevska" as an example to consider the process of optimization and selection of the mining equipment according to the parameter of the "prime cost".

\section{Optimization of operational parameters of the mining equipment}

The task is in the optimum choice of the technological chain of the mining equipment for specified operational conditions (Table 2).

Table 2. Features of mining faces in mines "Krasnolymanska" and "Kotliarevska".

\begin{tabular}{|l|c|c|c|c|c|}
\hline \multirow{2}{*}{ Mine } & $\begin{array}{c}\text { Layer } \\
\text { thickness, } \mathrm{m}\end{array}$ & $\begin{array}{c}\text { Face } \\
\text { length, } \mathrm{m}\end{array}$ & $\begin{array}{c}\text { Powered } \\
\text { support type }\end{array}$ & $\begin{array}{c}\text { Shearer } \\
\text { type }\end{array}$ & $\begin{array}{c}\text { Armoured face } \\
\text { conveyor type }\end{array}$ \\
\cline { 2 - 6 } & $m_{n}$ & $l_{n}$ & $t_{n}$ & $c_{n}$ & $k_{n}$ \\
\hline Krasnolymanska & $1.10-1.15$ & 295 & DM & RKU10 & SP251 \\
\hline Kotliarevska & $1.20-1.25$ & 250 & $1 \mathrm{KD} 90$ & $1 \mathrm{~K} 101$ & SP26 \\
\hline
\end{tabular}

To solve this task, we analyzed existing options for the integration of the mining face under given operational conditions. There are 57 such options for mines of Donbas. After the setting the minimum level of performance $Q \geq 1200 \mathrm{t} /$ day, the number of alternatives was reduced to 9 . 
However, 4 conditions remained for the mine "Krasnolymanska" and 3 conditions for the mine "Kotliarevska". Depending on the number of conditions (limitations), the result will be different, since this is the property of "structural optimization". Table 3 lists possible options available for the integration of mining faces for conditions of mines "Krasnolymanska" and "Kotliarevska".

Table 3. Possible options of completing for mining faces of mines "Krasnolymanska" and "Kotliarevska".

\begin{tabular}{|c|c|c|c|c|}
\hline \multirow{2}{*}{ No. } & \multicolumn{3}{|c|}{ Equipment types } & \multirow{2}{*}{ Designation in Fig. 1 } \\
\cline { 2 - 4 } & powered support & shearer & armoured face conveyor & \\
\hline 1 & KD80 & KA80 & SP251 & 1 \\
\hline 2 & DM & RKU10 & SP26 & 3 \\
\hline 3 & KD80 & KA80 & SP250 & 4 \\
\hline 4 & 1KD90 & 1 K101 & SP26 & 5 \\
\hline 5 & DM & UKD200 & SP326 & 6 \\
\hline 6 & 1KD90 & 1K101 & SP326 & 7 \\
\hline 7 & KD80 & 1K101 & SP250 & 8 \\
\hline 8 & DM & K103 & SP250 & 9 \\
\hline 9 & 1KD90 & UKD400 & SP326 & \\
\hline
\end{tabular}

For the mine "Krasnolymanska", requirements were as follows: low ash content of coal (excluding the alternative 2), series production of equipment (excluding the alternative 8), and screw type of the executive body (excluding alternatives 1,3), interrelation of shearer and armoured face conveyor (excluding the alternative 4). In the end, 4 possible options were left $(5,6,7,9)$. Similarly, the choice was made for the mine "Kotliarevska". It is convenient to present the selection process in the form of a decision-making "tree" (Fig. 1).

$a$

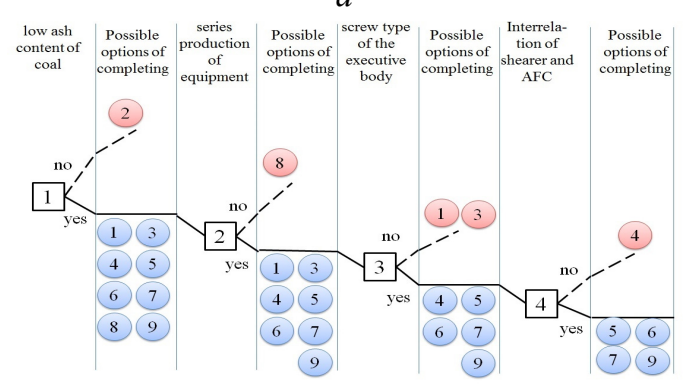

$b$

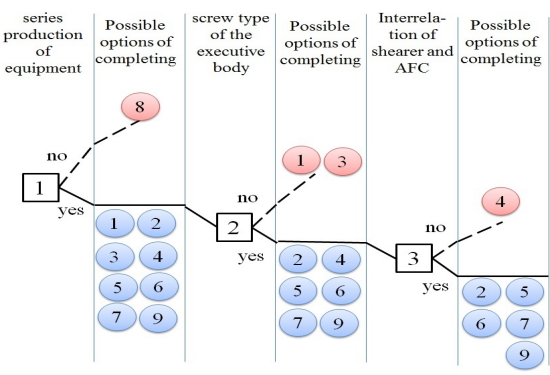

Fig. 1. Decision-making trees at different limitations: a - mine "Krasnolymanska", b - mine "Kotliarevska".

After the preliminary analysis of alternatives, one should choose a single alternative, optimal from the standpoint of minimization of the optimization parameter. In our case, this is the "production prime cost". We shall use the mine "Krasnolymanska" as an example to show the selection of the optimal chain of proposed options. To do this, let us present 4 options in the form of a network model. Vertices represent types of purification equipment, and the lengths between peaks are the values of specific cost (Table 4).

To automate the selection process, the personnel of the Institute of Physics of the Mining Processes of National Academy of Sciences of Ukraine developed the appropriate software [28 - 30]. The program will then automatically find the shortest route that will match the means of mechanization of the mining face, with a given level of performance $Q \geq 1200 \mathrm{t} /$ day and the minimum prime cost. 
Table 4. Data required for optimization.

\begin{tabular}{|c|c|c|c|c|c|}
\hline No. & $\begin{array}{c}\text { Equipment } \\
\text { type }\end{array}$ & $\begin{array}{c}\text { Costs for the } \\
\text { purchase, mln UAH }\end{array}$ & $\begin{array}{c}\text { Equipment life, } \\
\text { mln tonnes }\end{array}$ & $\begin{array}{c}\text { Prime cost, } \\
\text { UAH/t }\end{array}$ & $\begin{array}{c}\text { Vertice of the network } \\
\text { model (Fig. 2) }\end{array}$ \\
\hline 1 & KD80 & 120.0 & 2.50 & 48 & 2 \\
\hline 2 & 1 KD90 & 193.5 & 5.00 & 39 & 3 \\
\hline 3 & DM & 249.6 & 7.50 & 34 & 4 \\
\hline 4 & UKD200 & 35.0 & 0.60 & 58 & 5 \\
\hline 5 & 1K101 & 15.0 & 0.29 & 52 & 6 \\
\hline 6 & UKD400 & 47.4 & 1.00 & 48 & 7 \\
\hline 7 & SP326 & 64.7 & 2.50 & 26 & 8 \\
\hline 8 & SP250 & 38.7 & 1.10 & 35 & 9 \\
\hline
\end{tabular}

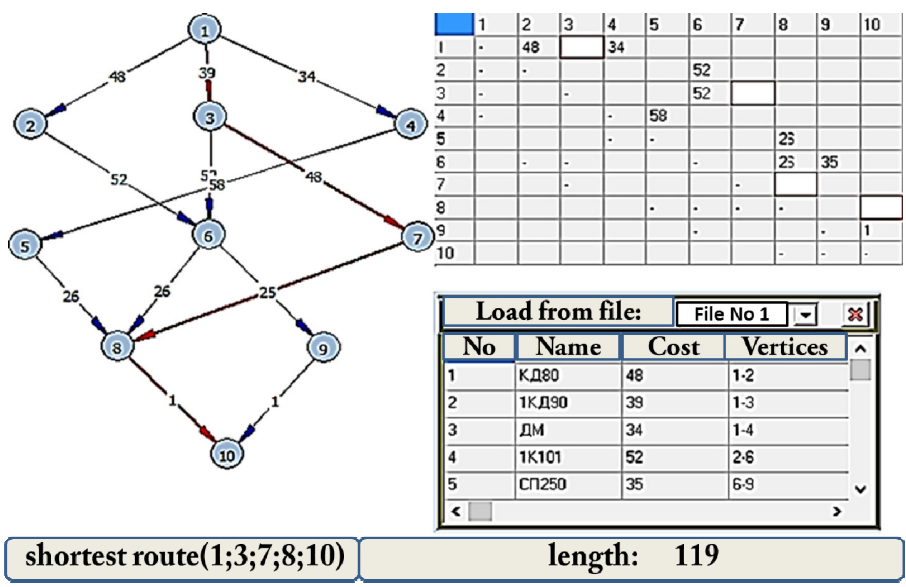

Fig. 2. Optimization of the process chain of the stopping equipment.

As can be seen from Figure 2, the shortest route is the one that passes through the following points: $1,3,7,8$, and 10 . This corresponds to the equipment chain "powered support 1KD90, shearer UKD400, armoured face conveyor SP326". However, when one uses powered support DM the production prime cost is lower than with powered support $1 \mathrm{KD} 90$, so let us rearrange the structure of the production chain. For this purpose, we shall find powered support, shearer, and armoured face conveyor with the lowest production prime cost. In the end, the optimum chain of the mining equipment will consist of powered support DM, shearer UKD400, armoured face conveyor SP326.

Table 5. Technical and economic analysis of proposed solutions.

\begin{tabular}{|}
$\mid$\begin{tabular}{|c|c|c|c|c|c|c|}
\hline $\begin{array}{c}\text { powered } \\
\text { support }\end{array}$ & shearer & $\begin{array}{c}\text { armoured face } \\
\text { conveyor }\end{array}$ & $\begin{array}{c}\text { Production } \\
\text { volume, t/day }\end{array}$ & $\begin{array}{c}\text { Increment, } \\
\text { t/day }\end{array}$ & $\begin{array}{c}\text { Prime } \\
\text { cost, } \\
\text { UAH/t }\end{array}$ & $\begin{array}{c}\text { Reduction } \\
\text { of prime } \\
\text { cost, UAH/t }\end{array}$ \\
\hline \multicolumn{7}{|c|}{ Mine "Krasnolymanska" } \\
\hline DM & RKU10 & SP251 & 1440 & - & 118 & - \\
\hline 1KD90 & UKD400 & SP326 & 1480 & $40(2.8 \%)$ & 113 & $5(4.2 \%)$ \\
\hline DM & UKD400 & SP326 & 1743 & $303(21.0 \%)$ & 108 & $10(8.5 \%)$ \\
\hline \multicolumn{7}{|c|}{ Mine "Kotliarevska" } \\
\hline 1KD90 & 1 K101 & SP26 & 848 & - & 124 & - \\
\hline DM & RKU10 & SP326 & 1272 & $424(48.3 \%)$ & 115 & $9(7.3 \%)$ \\
\hline
\end{tabular}
\end{tabular}


The program contains a database, provides various options for entering information and is integrated with office applications. For the purpose of optimization, we shall place points in the working area and set the length between points that correspond to vertices.

Because of the conducted selection, the prime cost will decrease by $10 \mathrm{UAH} / \mathrm{t}$ that will decrease the prime cost by $7.1 \mathrm{mln}$ UAH (Table 5). For the mine "Kotliarevska", we also conducted the selection and optimization of operational parameters. Table 5 shows the analysis of proposed solutions.

Thus, the improvement of the mechanized coal mining is in the choice of means of mechanization of the mining face with a given level of performance. Subsequent application of network models and graphs allows optimizing the chain at one of the options. The described approach can be used as an addition to the already known ways of the planning mining works $[31-32]$.

\section{Conclusions}

The study found that the performance of the mining face is an integral indicator, which is formed by a group of technological (layer thickness, length of the mining face), operational (means of mechanization), and economic factors. The effectiveness of the enterprise functioning is directly proportional to the level of interrelation between means of mechanization and inversely proportional to resources involved. This allowed us to draw the following conclusions:

- designing the technology for the mechanized coal mining is in the analysis of the set of rational solutions for specified operational conditions. Possible rational solutions can be formalized in the form of the "bank of decisions". This formalization allows to apply methods of structural optimization, analytic hierarchy process, linear and dynamic programming, and the graph interpretation allows automating the analysis process, increasing the dimension of solvable problems, which are found during the operation of coal fields;

- significant reserve of increasing technical and economic parameters of enterprises at the mining complex is the balanced flow of input and output resources; for this, it is necessary to present them in an organized structure as a network model. The subsequent application of optimization methods allows us to find the shortest route in the network, which corresponds to the balance of resources;

- scope of the described approach is not limited to coal fields and selection process of means of mechanization. Network models can be used to solve transportation problems, formulate emergency response plan, organize and manage resources, reduce the cost of equipment maintenance and repair.

One of the advantages of the proposed tool is its clearness, simplicity, ability to process and store large amounts of data. The characteristic feature of tools described in the paper is the ability to apply them together with MCDA methods at any stage of the study.

Authors express gratitude for the help and consultations during work performing for maintenance manager of "Krasnolymanska" mine Mykola Kostiev.

\section{References}

1. Ataei, M., Jamshidi, M., Sereshki, F., \& Jalali I. (2008). S.M.E. Mining method selection by AHP approach. Journal of the Southern African Institute of Mining and Metallurgy, 108(12), 741-749.

2. Mikaeil, R., Naghadehi, M., Ataei, M., \& Khalokakaie, R. (2009). A decision support system using fuzzy analytical hierarchy process (FAHP) and TOPSIS approaches for selection of the optimum underground mining method. Archives of Mining Sciences, 54(2), 349-368. 
3. Saaty, T., \& Shang, J. (2011). An innovative orders - of-magnitude approach to AHP-based Mutli-criteria decision making: Prioritizing divergent intangible humane acts. European Journal of Operational Research, 214(3), 703-715. http://dx.doi.org/10.1016/j.ejor.2011.05.019

4. Dehghani, H., Siami, A., \& Haghi, P. (2017). A new model for mining method selection based on grey and TODIM methods. Journal of Mining \& Environment, 8(1), 49-60. http://dx.doi.org/10.22044/JME.2016.626

5. Tzeng, G., \& Huang, J. (2011). Multiple attribute decision making: Methods and applications. Boca Raton, FL, USA: Chapman and Hall/CRC Press.

6. Wang, Ch., Tu, Sh., Zhang, L., Yang, Q., \& Tu, H. (2015). Auxiliary transportation mode in a fully-mechanized face in a nearly horizontal thin coal seam. International Journal of Mining Science and Technology, 25(6), 963-968. https://doi.org/10.1016/j.ijmst.2015.09.013

7. Zhang, J. \& Wang, Zh. (2012). The selection of coal strategic suppliers to the electric power enterprises based on cooperative game. China Coal, 3(4), 230-240.

8. Opricovic, S., \& Tzeng, G.-H. (2007) Extended VIKOR method in comparison with outranking methods. European Journal of Operational Research, 178(2), 514-529. https://doi.org/10.1016/j.ejor.2006.01.020

9. Grujic, M., \& Tomasevic, A. (1996). Choice of outside transportation system in underground coal mines by multiple criteria analysis. Underground Mining Engineering, 4(1), 62-70.

10. Vujić, S., Miljanović, I., Milutinović, A., Đorđević, D., Gojković, N., \& Gajićet, G. (2011). Multiattributive prediction of terrain stability above underground mining operations. Yugoslav Journal of Operations Research, 21(2), 275-291. https://doi.org/10.2298/YJOR1102275V

11. Nazymko, V.V. (2013). Pytannia pobudovy systemy avtomatyzovanoho upravlinnia proektom. Upravlinnia rozvytkom sklatnykh system, (14), 61-67.

12. Zakharova, L.N., \& Nazymko, V.V. (2012). Doslidzhennia chutlyvosti prohramy rozvytku hirnychykh robit ta yii ryzykiv $\mathrm{v}$ umovakh vuhilnoi shakhty. Radioelektronni $i$ kompiuterni systemy, 53(1), 157-164.

13. Iphar, M., \& Alpay, S. (2018) A mobile application based on multi-criteria decision-making methods for underground mining method selection. International Journal of Mining, Reclamation and Environment, 126(3), 69-77. https://doi.org/10.1080/17480930.2018.1467655

14. Bogdanovic, D., Nikolic, D., \& Ilic, I. (2012). Mining method selection by integrated AHP and PROMETHEE method. Anais da Academia Brasileira de Ciências, 84(1), 219-233. http://dx.doi.org/10.1590/S0001-37652012000100023.

15. Grinev, V., Cherepovskiy, P. \& Deulenko, A. (2014). Tekhnologicheskiy aspekt formirovaniya ob'ema dobychi uglya s pozitsyi rynochnykh modeley. Fiziko-tekhnicheskie problemy gornogo proizvodstva, (17), 117-125.

16. Grinev, V. (2016). Grafy i seti dlya vybora gorno-shahtnogo oborudovaniya. Dnipro: Porogy.

17. Khorolskyi, A.A., Grinov, V.G., \& Synkov, V.G. (2016). Vybir kompleksiv hirnycho-shakhtnoho obladnannia na osnovi teorii hrafiv. Visnyk Natsionalnoho Tekhnicnoho Universytetu Ukrainy "Kyivskyi Politekhnicnyi Instytut", (31), 57-64. https://doi.org/10.20535/2079-5688.2016.31.69892

18. Fioroni, M., Santos, Letícia, C., Franzese, L., Seixas, J., Penna, B., \& Alkmim, G. (2014). Logistic evaluation of an underground mine using simulation. Rem: Revista Escola de Minas, 67(4), 447-454. https://dx.doi.org/10.1590/0370-44672014670181

19. Brazil, M., Thomas, D.A., \& Weng, J.F. (2005). Cost Optimization for Underground Mining Networks. Optimization and Engineering, 6(2), 241-256. https://doi.org/10.1007/s11081-005$\underline{6797-\mathrm{X}}$

20. Guang. X., Jinxin, H., Baisheng, N., Chalmers, D. \& Zhuoming, Y. (2017). Calibration of Mine Ventilation Network Models Using the Non-Linear Optimization Algorithm. Energy, 31(11), 1119. https://doi.org/10.3390/en11010031

21. Amankwah, H. (2011). Mathematical Optimization Models and Methods for Open-Pit Mining. Ph.D. Linköping University. 
22. Shi, Q., \& Erhan, K. (2016). New graph-based algorithms to efficiently solve large scale open pit mining optimization problems. Expert Systems with Applications, 43(1), 59-65. https://doi.org/10.1016/j.eswa.2015.08.044

23. Vladyko, O., Kononenko, M., \& Khomenko, O. (2012). Imitating modeling stability of mine workings. Geomechanical Processes During Underground Mining: School of Underground Mining 2012, 147-150. https://doi.org/10.1201/b13157-26

24. Kirsch, U. (1981). Optimum Structural Design: Concepts, Methods and Applications. New York: McGraw-Hill.

25. Blauberg, I.V., Sadovskiy, V.N., \& Yudin, E.G. (1978). Filosofskiy printsyp sistemnosti i sistemnyy podkhod. Voprosy filosofii, (8), 39-52.

26. O'Connor, J., \& Mc. Dermott, I. (1997). The art of systems thinking: essential skills for creativity and problem solving. London: Thorsons.

27. Pidd, M. (2004). Systems Modelling: Theory and Practic. West Sussex: Wiley.

28. Grinev, V.G. \& Khorolskiy, A.A. (2017). Obosnovanie parametrov vybora komplektatsii ochistnogo oborudovaniya s uchetom oblasti ratsional'noy ekspluatatsii. Visti Donetskoho Hirnuchoho Instytutu, 40(1), 139-144.

29. Khorolskiy, A.A. \& Grinev, V.G. (2018). Setevye modeli kak instrument povysheniya organizatsionno-tekhnologicheskoy nadezhnosti proizvodstva. In Innovative Technologies in Education, Science and Production. Minsk: Belarusian National Technical University. https://rep.bntu.by/handle/data/36360

30. Khorolskyi, A.A., \& Hrinov, V.G. (2017). Systemni pryntsypy ta otsinochni kryterii nadiinosti pry optymizatsii tekhnolohichnykh skhem vuhilnykh rodovyshch. Visnyk Zhytomyrskoho Derzhavnoho Tekhnolohichnoho Universytetu, 80(2), 225-233. https://doi.org/10.26642/tn-20172(80)-225-233

31. Mamaikin, O.R. (2014). Obhruntuvannia parametriv tekhnolohichnykh skhem antratsytovykh shakht dlia ikh adaptatsii do innovatsii. Ph.D. Natsionalnyi hirnychyi universytet.

32. Brazil, M., \& Thomas, D. (2007). Network optimization for the design of underground mines. Networks, 49(1), 40-50. https://doi.org/10.1002/net.20140 